\title{
DIFFERENCES IN THE VALUE SYSTEM OF VULNERABLE PREADOLESCENTS
}

\author{
Florin PELIN ${ }^{1}$, Radu PREDOIU ${ }^{1}$, Georgeta MITRACHE ${ }^{1}$, \\ Corina CIOLCĂ ${ }^{1}$, Dan BADEA ${ }^{1}$, Alexandra PREDOIU ${ }^{1 *}$ \\ ${ }^{1}$ National University of Physical Education and Sports, Faculty of Physical Education and Sport, \\ 140 Constantin Noica Street, Bucharest, Romania \\ *corresponding author: alexandra.predoiu@yahoo.com
}

https://doi.org/10.52846/jskm/37.2021.1.3

Abstract: Values are linked to how an individual perceives the environment and himself, being context-determined. The aim of our investigation was to identify the value structure of pre-teens in risk of school dropout according to gender and type of vulnerability. We mention that physical education and sports provide opportunities for socialization and, at the same time, facilitate social integration. Therefore, in order to prevent and reduce social exclusion and school dropout, specialists must take into account the essential role that sport plays for children from vulnerable groups (and not only). A total of one hundred and nineteen preadolescents (67 boys and 52 girls), in risk of school dropout, participated in the research. The Values Questionnaire (part of the PEDb computerized platform) was used. The results emphasized that, in the case of socially assisted preadolescents, the scores for autonomy and authority are significantly higher in boys, compared to girls. When talking about pre-teens in which case a parent is missing, we found that: skills development value is significantly more important for girls than boys; boys value more respecting rules, authority, challenge, professional recognition and social relations, while for girls, skills development, autonomy, security and free time are more important. Through one-way MANOVA, after comparing socially assisted preadolescents with pre-teens in which case a parent is missing and with Roma people (socially assisted), interesting data were also highlighted, in terms of values held. Knowing the value structure of pre-teens in risk of school dropout, teachers, psychologists, parents can positively influence pre-teens' sustainable social and educational integration.

Keywords: pre-teens, value structure, school dropout, vulnerability, personality.

\section{Introduction}

Vulnerability (from a psychological point of view) disturbs the relational, affective and cognitive activity of a person (Predoiu et al., 2020). Vulnerability varies with age - is more pronounced in childhood and supposes therapeutic, but also preventive interventions (Doron \& Parot, 2006). A vulnerable student becomes more easily stressed, anxious, creating the premises for school dropout. We mention that poverty is one of the main reasons, influencing the decision to drop out of school (Merce et al., 2015). We can add family involvement (considering the educational process), the quality of the relations established by the student with colleagues, teachers etc., personality structure (innate determination and acquired features), all influencing the level of self-efficacy and the student's ability to withstand various stressors (Mitrache et al., 2018).

Specialized literature discusses about ten basic values (e.g., tradition, achievement, security, hedonism, power, conformity etc.), which can be observed regardless the society (see Schwartz \& Boehnke theory, 2004). Gender differences were found - power, hedonism, stimulation and achievement values seem to be more important for men than women (Schwartz \& Rubel, 2005). Values suppose modes of conduct which transcend specific environmental conditions, being seen as abstract beliefs about desirable goals (Fischer, 2018).

The value system of a person is integrated in the personality structure. We can think at the character (the relational-value subsystem of personality) - Mitrache and Predoiu (2016). Character, moral values are known to promote social adaptation (Svrakic \& Divac-Jovanovic, 2019).

Perhaps the most recognized researcher who has studied values is Schwartz (see Schwartz, 2006; Bardi \& Schwartz, 2003; Schwartz, 1996). According to the author and his collaborators, values: guide the evaluation 
and the selection of people or actions; are linked to various behaviours (serve as standards) and have relative stability (do not change easily), being organized in a hierarchical system. Researchers are talking also about the possibility that the values vary depending on the circumstances. Therefore, Bardi et al. (2009) or Rudnev (2014) asserted that when we face difficult situations (or perceived as dangerous), some values, beliefs, may vary to some degree. In this case, the hierarchy of values is changing. However, as Vecchione et al. (2016) stated, the value system/ structure remains the same, even if some values become more important than others.

The process of value formation (in sport domain) is significantly influenced by the positive (and negative) reinforcements, the explicit teaching and the specialist's behavior (Kim, 2020). When talking about age, it negatively correlates with hedonism, stimulation and self-direction values, and is positively associated with security, tradition and conformity (Robinson, 2013; Milfont et al., 2016).

We mention the fact that physical education (PE) and sports contribute to the process of transforming the child into an adult and to his integration into society. By enabling pre-teens, for example, with motor, biological, functional, mental and moral skills, the two activities (PE and sports) have become indispensable in the process of harmonious development of personality. As stated by the European Commission, it is very important to provide children (disabled or not) with as many opportunities to engage in physical activity as possible. Therefore, we must take into account the special role that sport can play for young people, people from disadvantaged groups and for people with disabilities (Commission of the European Communities, 2007).

Specialists pay special attention to social integration through sport (Duret, 2008), at the level of all subsystems:

- in sports for all, individuals feel the need to be part of a group with common goals, but also to communicate with others; cooperation involves the presence of the motivation of affiliation, security, members of the group who have a common goal organizing their actions in such a way as to overcome the opposing group (Epuran, 2013);

- in performance sports, there are champions for whom sport is a beneficial framework for social compensation and integration into an environment in which they are appreciated;

- in adapted sports, people with disabilities find effective ways to integrate into sports groups/ teams, overcoming social barriers.

By involving children in PE and sports activities, they acquire and develop values such as responsibility, fair play and a spirit of competition. Also, shy children, who over time were involved in sports activities, reported a significant decrease in anxiety levels (Findlay \& Coplan, 2008).

Physical education and sports lessons "provide opportunities for socialization and, at the same time, facilitate social integration" (Bichescu, 2009), thereby contributing to the prevention and reduction of social exclusion and school dropout. The specific environment, together with the projected learning and practice situations, allow the experimentation of different types of interaction, from cooperation to competitiveness. Specialists (Dragnea \& Teodorescu, 2002) talk about the different roles that participants play during sports games, roles through which they learn to react and adapt to various group situations, learn to belong to a group, to develop their skills, communication and make friends. Children learn to be more responsible and loyal to the people and institutions that impose the rules of the game. Therefore, sports activities have an essential contribution in terms of social cohesion and the formation of more integrated societies.

Regarding the value system of preadolescents in risk of school dropout, we mention a gap in the literature. The aim of our investigation was to identify the value structure of pre-teens in risk of school dropout according to gender and type of vulnerability. 


\section{Materials and method \\ Participants}

One hundred and nineteen preadolescents (67 boys and 52 girls), in risk of school dropout, participated in the research. The students were randomly selected, from the sixth, seventh and eighth grade, from five schools in Romania: one in Bucharest, one school in Mehedinți county and three schools in Vaslui county. The average age was 13.6 years. We present the distribution of participants (type of vulnerability and gender):

- 76 preadolescents which are socially assisted ( 38 boys and 38 girls);

- 28 pre-teens in which case a parent is missing (18 boys - 13 pre-teens have a parent who works abroad, 4 preadolescents come from disorganized families and one from single-parent family and 10 girls - 5 students have a parent who works abroad, 3 pre-teens come from disorganized families, and 2 from single-parent families);

- 15 Roma people being socially assisted (11 boys and 4 girls).

\section{Measures}

Part of the PEDb computerized platform (designed by Cognitrom company), The Value Questionnaire was used - we mention that the questionnaire is calibrated for the Romanian population.

The Value Questionnaire consists of 36 verbal items, being emphasized 9 values (scales).
The students were asked to rate how much they believe they resemble the person described in each item - the Schwartz method was used when creating the questionnaire Schwartz (2004). Thus, $5=$ Resembles me to a great extent, $4=$ Resembles me a lot, $3=$ Resembles me to a certain extent, $2=$ Resembles me a little and $1=$ Resembles me to a very small extent.

The nine values are: respecting rules; skills development; free time; social relations; challenge; authority; autonomy; security and professional recognition.

\section{Procedure}

The pre-teens completed The Values Questionnaire between July 2020 and February 2021. The investigation was conducted both face to face, online (via google meet) and by phone (due to the COVID-19 pandemic). Regarding the ethical principles - preadolescents were informed that they could withdraw at any time, while the confidentiality (when talking about data) and the anonymity of the preadolescents were ensured.

\section{Results}

Through independent $t$ test we wanted to identify if there are significant differences between boys and girls, in the case of socially assisted pre-teens (the Levene test is insignificant, $\mathrm{p}>0.05$ ).

Table 1. Descriptive statistics - socially assisted preadolescents (boys and girls)

\begin{tabular}{|c|c|c|c|c|}
\hline Values & Gender & Mean & Std. Deviation & Std. Error Mean \\
\hline \multirow{2}{*}{ free time } & $\mathrm{B}$ & 79.61 & 12.102 & 1.963 \\
\cline { 2 - 5 } & $\mathrm{G}$ & 81.21 & 14.796 & 2.400 \\
\hline \multirow{2}{*}{ respecting rules } & $\mathrm{B}$ & 77.89 & 13.388 & 2.172 \\
\cline { 2 - 5 } & $\mathrm{G}$ & 81.32 & 13.032 & 2.114 \\
\hline \multirow{2}{*}{$\begin{array}{c}\text { professional } \\
\text { recognition }\end{array}$} & $\mathrm{B}$ & 74.34 & 15.560 & 2.524 \\
\cline { 2 - 5 } social relations & $\mathrm{G}$ & 73.95 & 10.915 & 1.771 \\
\hline \multirow{2}{*}{ security } & $\mathrm{B}$ & 81.45 & 12.940 & 2.099 \\
\hline & $\mathrm{G}$ & 82.50 & 11.375 & 1.845 \\
\cline { 2 - 5 } & $\mathrm{B}$ & 65.92 & 15.016 & 2.436 \\
\hline \multirow{2}{*}{ autonomy } & $\mathrm{G}$ & 65.53 & 14.832 & 2.406 \\
\cline { 2 - 5 } & $\mathrm{B}$ & 80.39 & 11.820 & 1.917 \\
\hline
\end{tabular}


Journal of Sport and Kinetic Movement No. 37,Vol. I/2021

\begin{tabular}{|c|c|c|c|c|}
\hline skills development & $\mathrm{B}$ & 79.47 & 12.776 & 2.073 \\
\cline { 2 - 5 } & $\mathrm{G}$ & 80.92 & 11.674 & 1.894 \\
\hline \multirow{2}{*}{ challenge } & $\mathrm{B}$ & 72.50 & 14.784 & 2.398 \\
\cline { 2 - 5 } & $\mathrm{G}$ & 73.16 & 12.380 & 2.008 \\
\hline \multirow{2}{*}{ authority } & $\mathrm{B}$ & 60.53 & 15.930 & 2.584 \\
\cline { 2 - 5 } & $\mathrm{G}$ & 51.45 & 17.472 & 2.834 \\
\hline
\end{tabular}

Table 2. Inferential statistics - socially assisted preadolescents

\begin{tabular}{|c|c|c|c|c|}
\hline \multirow{2}{*}{ Values } & \multirow{2}{*}{$\mathbf{t}$} & \multirow{2}{*}{$\begin{array}{c}\text { 95\% Confidence Interval } \\
\text { of the Difference }\end{array}$} \\
\cline { 4 - 5 } & & & $\begin{array}{c}\text { Lower } \\
\text { Upper }\end{array}$ \\
\hline free time & -.518 & .606 & -7.784 & 4.573 \\
\hline respecting rules & -1.129 & .263 & -9.460 & 2.618 \\
\hline professional recognition & .128 & .898 & -5.749 & 6.538 \\
\hline social relations & -.377 & .708 & -6.622 & 4.516 \\
\hline security & .115 & .909 & -6.427 & 7.217 \\
\hline autonomy & 2.060 & .043 & .215 & 12.943 \\
\hline skills development & -.516 & .608 & -7.041 & 4.147 \\
\hline challenge & -.210 & .834 & -6.891 & 5.575 \\
\hline authority & 2.367 & .021 & 1.436 & 16.722 \\
\hline
\end{tabular}

Analyzing Table 2 we can emphasize that the mean scores for autonomy and authority are significantly higher $[\mathrm{t}(74)=2.060, \mathrm{p}=0.043$ - autonomy; $\mathrm{t}(74)=2.367, \mathrm{p}=0.021$ - authority $]$ in boys, compared to girls. The Hedge's g value (effect size) is 0.47 (autonomy), respectively 0.54 (authority), which reflects a moderate difference (Predoiu, 2020) between the values for autonomy and authority. The confidence interval is comprised between 0.215 (lower limit) and 12.943 (upper limit), in the case of autonomy, respectively between 1.436 (lower limit) and 16.722 (upper limit), in the case of authority.

When talking about the other values, no significant differences were found, in the case of socially assisted pre-teens, according to the gender.

Both boys and girls value more the social relations, free time and skills development. We mention, also, that autonomy is more important for boys, while respecting rules for girls - Table 1 (socially assisted pre-teens).

Using Mann-Whitney (U) test we checked, also, if there are important differences between girls and boys, in students in which case a parent is missing (from the point of view of the 9 investigated values).

Table 3. Descriptive statistics - pre-teens in which case a parent is missing

\begin{tabular}{|c|c|c|c|c|}
\hline Values & Gender & N & Mean Rank & Sum of Ranks \\
\hline \multirow{2}{*}{ free time } & $\mathrm{B}$ & 18 & 13.69 & 246.50 \\
\cline { 2 - 5 } & $\mathrm{G}$ & 10 & 15.95 & 159.50 \\
\hline \multirow{2}{*}{ respecting rules } & $\mathrm{B}$ & 18 & 14.86 & 267.50 \\
\cline { 2 - 5 } & $\mathrm{G}$ & 10 & 13.85 & 138.50 \\
\hline \multirow{2}{*}{ professional recognition } & $\mathrm{B}$ & 18 & 14.22 & 256.00 \\
\cline { 2 - 5 } & $\mathrm{G}$ & 10 & 15.00 & 150.00 \\
\hline \multirow{2}{*}{ social relations } & $\mathrm{B}$ & 18 & 14.33 & 258.00 \\
\cline { 2 - 5 } & $\mathrm{G}$ & 10 & 14.80 & 148.00 \\
\hline \multirow{2}{*}{ security } & $\mathrm{B}$ & 18 & 13.75 & 247.50 \\
\cline { 2 - 5 } & $\mathrm{G}$ & 10 & 15.85 & 158.50 \\
\hline
\end{tabular}




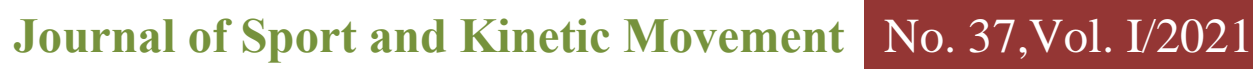

\begin{tabular}{|c|c|c|c|c|}
\hline \multirow{2}{*}{ autonomy } & B & 18 & 12.64 & 227.50 \\
\cline { 2 - 5 } & G & 10 & 17.85 & 178.50 \\
\hline \multirow{2}{*}{ skills development } & B & 18 & 12.22 & 220.00 \\
\cline { 2 - 5 } & G & 10 & 18.60 & 186.00 \\
\hline \multirow{2}{*}{ challenge } & B & 18 & 14.53 & 261.50 \\
\cline { 2 - 5 } & G & 10 & 14.45 & 144.50 \\
\hline authority & B & 18 & 14.61 & 263.00 \\
\cline { 2 - 5 } & G & 10 & 14.30 & 143.00 \\
\hline
\end{tabular}

Table 4. Inferential statistics - pre-teens in which case a parent is missing

\begin{tabular}{|c|c|c|c|c|c|c|c|c|c|}
\hline & F & R & PR & SR & SEC & AUT & SD & C & AH \\
\hline Mann-Whitney & 75.5 & 83.5 & 85.0 & 87.0 & 76.5 & 56.5 & 49.0 & 89.5 & 88.0 \\
\hline $\mathrm{Z}$ & -.70 & -.31 & -.242 & -.146 & -.65 & -1.61 & -1.98 & -.02 & -.09 \\
\hline $\mathrm{p}$ & .494 & .759 & .832 & .906 & .524 & .109 & .047 & .981 & .944 \\
\hline
\end{tabular}

Note: $\mathrm{F}$ - free time; $\mathrm{R}$ - respecting rules; PR - professional recognition; SR - social relations; SEC - security;

AUT - autonomy; SD - skills development; $\mathrm{C}$ - challenge; $\mathrm{AH}$ - authority.

The Mann-Whitney test result considering skills development is 49 . Whereas $p=0.047$, we may conclude that between girls and boys there are significant differences - skills development value is significantly more important for girls than boys, in preadolescents in which case a parent is missing. The effect size is $r=0.38$, meaning that the effect of the group variable (girls/ boys) on the scores for skills development, is moderate to strong.

Boys value more respecting rules, authority, challenge, professional recognition and social relations, while for girls, skills development, autonomy, security and free time are more important Table 3 (pre-teens in which case a parent is missing).

Not least, we analyzed if there are significant differences regarding the value system of pre-teens, depending on the type of vulnerability. We compared socially assisted preadolescents, pre-teens in which case a parent is missing and Roma people (socially assisted). One-way MANOVA was used in order to verify these differences (type I procedure - SPSS 20). The dependent variables positively correlate with each other (there are weak or moderate correlations) - linearity assumption being underlined. The Box M test value is 0.016 , therefore, we analyzed the Wilks' Lambda test. Also, we mention that homogeneity of variance was assured (Levene test) and we interpreted the Scheffe test. We highlighted (post hoc tests) that there are not significant differences between the three groups of preadolescents (considering the type of vulnerability), from the point of view of the nine investigated values (Scheffe test, $\mathrm{p}>0.05$ ).

However, interesting differences could be underlined (Table 5).

Table 5. Descriptive statistics - pre-teens (type of vulnerability)

\begin{tabular}{|c|c|c|c|c|}
\hline Values & Type of vulnerability & Mean & Std. Deviation & N \\
\hline \multirow{3}{*}{ free time } & Roma people & 75.67 & 13.478 & 15 \\
\cline { 2 - 4 } & socially assisted & 80.41 & 13.450 & 76 \\
\cline { 2 - 4 } & a parent is missing & 79.29 & 11.524 & 28 \\
\hline \multirow{3}{*}{ respecting rules } & Roma people & 80.00 & 12.536 & 15 \\
\cline { 2 - 4 } & socially assisted & 79.61 & 13.235 & 76 \\
\cline { 2 - 4 } & a parent is missing & 77.50 & 15.486 & 28 \\
\hline \multirow{3}{*}{ professional recognition } & Roma people & 74.33 & 21.370 & 15 \\
\cline { 2 - 4 } & socially assisted & 74.14 & 13.351 & 76 \\
\cline { 2 - 4 } & a parent is missing & 73.39 & 16.502 & 28 \\
\hline \multirow{2}{*}{ social relations } & Roma people & 88.67 & 9.722 & 15 \\
\cline { 2 - 4 } & socially assisted & 81.97 & 12.113 & 76 \\
\hline
\end{tabular}


Journal of Sport and Kinetic Movement No. 37,Vol. I/2021

\begin{tabular}{|c|c|c|c|c|}
\hline & a parent is missing & 85.71 & 13.313 & 28 \\
\hline \multirow{4}{*}{ security } & Roma people & 64.33 & 14.744 & 15 \\
\cline { 2 - 4 } & socially assisted & 65.72 & 14.826 & 76 \\
\cline { 2 - 4 } & a parent is missing & 71.96 & 14.990 & 28 \\
\hline \multirow{3}{*}{ autonomy } & Roma people & 78.00 & 7.270 & 15 \\
\cline { 2 - 4 } & socially assisted & 77.11 & 14.219 & 76 \\
\cline { 2 - 4 } & a parent is missing & 79.29 & 14.123 & 28 \\
\hline \multirow{3}{*}{ skills development } & Roma people & 76.00 & 15.376 & 15 \\
\cline { 2 - 4 } & socially assisted & 80.20 & 12.178 & 76 \\
\cline { 2 - 4 } & a parent is missing & 77.68 & 12.284 & 28 \\
\hline \multirow{3}{*}{ challenge } & Roma people & 72.67 & 12.659 & 15 \\
\cline { 2 - 4 } & socially assisted & 72.83 & 13.548 & 76 \\
\cline { 2 - 4 } & a parent is missing & 75.36 & 13.189 & 28 \\
\hline authority & Roma people & 63.33 & 13.318 & 15 \\
\cline { 2 - 4 } & socially assisted & 55.99 & 17.224 & 76 \\
\cline { 2 - 4 } & a parent is missing & 60.71 & 20.263 & 28 \\
\hline
\end{tabular}

We emphasize that:

- Roma people (boys and girls) value more professional recognition, respecting rules, social relations and authority (compared to other groups);

- Socially assisted pre-teens value more free time and skills development;

- Pre-teens in which case a parent is missing value more security, autonomy and challenge (when comparing to the other two groups of preadolescents).

\section{Conclusion}

The aim of our investigation was to identify the value structure of pre-teens in risk of school dropout according to gender and type of vulnerability.

First, we emphasized that the mean scores for autonomy and authority are significantly higher in boys, compared to girls (in socially assisted preadolescents). We can say that for boys (compared to girls), it is significantly more important to have diversity in actions, great freedom, to make plans according to their standards, to have influence over others and to lead them. We underline, also, that in the case of socially assisted pre-teens, both boys and girls value social relations, free time and skills development, for boys autonomy is more important, while respecting rules for girls.

Second, we analyzed the differences between girls and boys, in students in which case a parent is missing. We found that skills development value is significantly more important for girls than boys. Also, it seems that boys value more respecting rules, authority, challenge, professional recognition and social relations, while for girls, skills development, autonomy, security and free time are more important (in the case of preteens in which case a parent is missing).

When investigating the differences regarding the value system of pre-teens, depending on the type of vulnerability, after running oneway MANOVA and post hoc tests we highlighted that there are not significant differences between the three groups of preadolescents: socially assisted, Roma people and students in which case a parent is missing. However, at a descriptive level, we can assert interesting aspects, which are worth mentioning: socially assisted preadolescents value more free time and skills development; Roma people value more professional recognition, respecting rules, social relations and authority, while for preteens in which case a parent is missing, security, autonomy and challenge values are very important (compared to other groups).

We specify that in order to increase social cohesion, in order to form more integrated 
societies, sports activities play a catalytic role. Engaging children, pre-teens and adolescents (with or without disabilities) in sports activities facilitates social integration, belonging and acceptance. PE and sport must become a priority when we want to prevent and reduce social exclusion and school dropout.

We mention that in-depth interviews must be used with pre-teens in order to better understand their value structure and why different components are valued more. We must be aware, also, that the COVID-19 pandemic could change a person's priorities the existing stressors in the external environment could influence value dynamics (some values may become more important than others). Future studies are required, investigating students at risk of school dropout, on larger samples and, also, at different ages (e.g., teens).

\section{Acknowledgement}

The study was carried out within the project entitled "Sustainable social and educational integration through sports activities - PNP001 2019-2023". We would like to thank our partner university, Norwegian School of Sport Sciences, and the colleagues Aage Radmann, Reidar Säfvenbom, Kristin Evensen \& Jörgen Eriksen for valuable and important input to the study.

\section{Authors' Contributions}

All authors have equally contributed to this study.

\section{References}

Bardi, A., Lee, J. A., Hofmann-Towfigh, N., \& Soutar, G. (2009). The structure of intraindividual value change. Journal of Personality and Social Psychology, 97, 913929. https://doi.org/10.1037/a0016617

Bardi A., \& Schwartz, S. H. (2003). Values and Behavior: Strength and Structure of Relations. Personality and Social Psychology Bulletin, 29, 1207-1222. https://doi.org/10.1177/0146167203254602

Bichescu, A. I. (2009). The specialist in physical education in the role of facilitator for the institutionalised children. Ovidius University Annals, Series Physical Education and
Sport/Science, Movement and Health, 9(2 Supplement), 349-354.

Commission of the European Communities. (2007). White Paper on Sport, Brussels. https://eur-lex.europa.eu/legal-

content/EN/TXT/PDF/?uri=CELEX:52007DC 0391\&from $=\mathrm{EN}$

Doron, R., \& Parot, F. (Ed.). 2006. Dicţionar de psihologie [Dictionary of psychology]. Humanitas.

Dragnea, A., \& Teodorescu, S. (2002). Teoria sportului [Sport theory]. FEST.

Duret, P. (2008). Sociologie du sport [Sociology of sport]. PUF.

Epuran, M. (2013). Motricitate şi psihism în activitățile corporale: Prolegomene la o metateorie a activităților corporale (Vol. 2) [Motor skills and psychism in bodily activities: Prolegomena to a meta-theory of bodily activities ( $2^{\text {nd }}$ Edition). FEST.

Findlay, L. C., \& Coplan, R. J. (2008). Come out and play: Shyness in childhood and the benefits of organized sports participation. Canadian Journal of Behavioural Science, 40(3), 153-161. https://doi.org/10.1037/0008400X.40.3.153

Fischer, R. (2018). Personality, Values, Culture: An Evolutionary Approach. Cambridge University Press.

Kim, S.-K. (2020). A Study on the teaching methods and values of Chinese taekwondo masters. Archives of Budo, 16, 203-210. WOS:000588351000001

Merce, I. I., Milin, I. A., Petroman, C., \& Ciolac, R. M. (2015). School dropout - a social problem in Romania. Procedia - Social and Behavioral Sciences, 182, 623-628. https://doi.org/10.1016/j.sbspro.2015.04.795

Milfont, T. L., Milojev, P., \& Sibley, C. G. (2016). Values stability and change in adulthood: A 3year longitudinal study of rank-order stability and mean-level differences. Personality and Social Psychology Bulletin, 42, 572-588. https://doi.org/10.1177/0146167216639245

Mitrache, G., \& Predoiu, R. (2016). Psihopedagogie - Ediţie revizuită [Psychopedagogy - Revised edition]. Discobolul.

Mitrache, G., Tüdös, Ş., \& Predoiu, R. (2018). Incursiune în psihologia educaţiei - profesorul de succes şi exigenţele contemporane [Journey into the psychology of education - the successful teacher and contemporary demands]. Discobolul. 
Predoiu, A. (2020). Metodologia cercetării științifice. Aplicații practice și elemente de statistică neparametrică [Scientific research methodology. Practical applications and elements of nonparametric statistics]. Discobolul.

Predoiu, R., Mihăilă, C.-V., Mitrache, G., Predoiu, A. (2020). Identifying the work styles of $1 \mathrm{st}$ year students from UNEFS using computerized assessment. Proceedings of the 16th International Scientific Conference "eLearning and Software for Education", 3, 397-403. DOI: 10.12753/2066-026X-20-223

Robinson, O. C. (2013). Values and adult age: Findings from two cohorts of the European Social Survey. European Journal of Ageing, 10, 11-23. https://doi.org/10.1007/s10433-0120247-3

Rudnev, M. (2014). Value adaptation among intra-European migrants role of country of birth and country of residence. Journal of Cross-Cultural Psychology, 45, 1626-1642. https://doi.org/10.1177/0022022114548482

Schwartz, S. H. (1996). Value priorities and behavior: Applying a theory of integrated value systems. In C. Seligman, J. M. Olson, \& M. P. Zanna (Eds.), The psychology of values: The Ontario Symposium, Vol. 8 (pp. 1-24). Erlbaum.

Schwartz, S. H. (2004). A Proposal for Measuring Value Orientations across Nations. European Social Survey. http://www.europeansocialsurvey.org/index.ph p?option=com_docman $\&$ task=doc_view $\&$ gid $=$ $126 \&$ Itemid $=80$

Schwartz, S. H. (2006). Les valeurs de base de la personne: théorie, mesures et applications [Basic Human Values: Theory, Methods, and Applications]. Revue Française de Sociologie, 47(4), 929-968.

Schwartz, S. H., \& Boehnke, K. (2004). Evaluating the structure of human values with confirmatory factor analysis. Journal of Research in Personality, 38(3), 230-255. https://doi.org/10.1016/S0092-6566(03)000692

Schwartz, S. H., \& Rubel, T. (2005). Sex differences in value priorities: Cross-cultural and multi-method studies. Journal of Personality and Social Psychology, 89(6), 1010-1028. DOI: $\quad$ 10.1037/00223514.89.6.1010

Svrakic, D. M., \& Divac-Jovanovic, M. (2019). The Fragmented Personality: An Integrative, Dynamic, and Personalized Approach to Personality Disorder. Oxford University Press. Vecchione, M., Schwartz, S., Alessandri, G., Doring, A. K., Castellani, V., \& Caprara, M. G. (2016). Stability and change of basic personal values in early adulthood: An 8-year longitudinal study. Journal of Research in Personality, 63, 111-122.

https://doi.org/10.1016/j.jrp.2016.06.002 